The Geneva Papers on Risk and Insurance, 18 (No. 68, July 1993), 219-223

\title{
Les vingt Ans de l'Association de Genève
}

\author{
par Fabio Padoa*
}

1. Vingt ans, moins d'un quart de siècle, à peine le temps d'un clin d'œil sur le visage auguste de l'histoire, mais aussi la moitié d'une vie professionnelle bien remplie! Embrassant d'un seul regard cette durée, saurions-nous y reconnaître quelques lignes communes, un itinéraire cohérent?

Deux souverains maîtres à penser de ce siècle, Teilhard et Steiner, nous serviront de repères. Le premier affirme qu'à l'humanité de notre époque la flèche de l'évolution indique un but commun, celui de l'unité planétaire, se réalisant par la voie d'aggrégations de plus en plus vastes. Le second distingue dans l'organisme social trois ordres de fonctions, qui embrassent respectivement les domaines de l'économie, de la culture et de la politique. Est-il déplacé de tenter d'analyser, à la lumière de ces deux propositions, le chemin parcouru par l'Association de Genève au cours de ces deux décennies et de tenter ainsi d'en définir la direction par rapport aux données de départ?

2. Il est indéniable que sur le plan économique les vingt dernières années ont vu avancer d'une façon remarquable l'intégration du monde où nous vivons. Les matières premières, les produits industriels, les mouvements de capitaux, les remous mêmes de la conjoncture ne connaissent plus de frontières. Les échanges ne cessent de s'intensifier entre tous les pays de la terre. La planétisation est pour ainsi dire achevée.

A un moindre degré, mais de façon tout de même très poussée, les activités de l'esprit sont communes à leurs adeptes dans le monde entier. Cela est vrai pour la recherche scientifique, qui ne se conçoit que dans le cadre d'un colloque continu au sein d'une communauté mondiale de savants. C'est vrai aussi pour les religions, qui recrutent leurs fidèles bien au-delà des divisions entre Etats et qui visent l'œcuménisme. C'est vrai enfin pour les arts, qui s'adressent en un même langage figuratif, plastique ou musical, aux publics les plus divers et lointains dans le monde entier.

De robustes barrières subsistent au contraire au niveau des institutions politiques. L'Etat national, dont le modèle est issu en Europe d'un procès de formation, d'une durée de cinq ou six siècles a engendré un tissu très serré de réalités juridiques, administratives et sociales, qui font obstacle aux solutions universelles. Il est bien vrai que les plus avancés parmi ces Etats évoluent vers de nouvelles formations supranationales, telles que l'Union des 12 , mais en revanche la prise de conscience des communautés territoriales différentes

* Président d'Honneur de l'Association de Genève. 
se dégageant de l'emprise des Empires coloniaux de l'Est et du Sud donne naissance à autant de nouveaux Etats nationaux. Les structures politiques et leurs retombées institutionnelles s'opposent par nature a l'orientation vers l'unité du monde actuel, si présente au contraire dans les domaines de l'économie et de la culture. Voici donc la ligne de faille du mouvement unificateur.

Or l'assurance, par son double caractère national (en tant que solidement enracinée sur le terrain institutionnel de l'Etat où elle s'exerce) et international (en tant que mécanisme de distribution des risques dans l'espace au-delà des frontières), joue un rôle exemplaire à l'heure où apparaît de façon aussi marquée la contradiction que nous venons de dénoncer. L'Association de Genève, lieu de recherche, d'analyse, de théorisation des données réelles, est donc toute désignée à représenter l'assurance comme un domaine d'avant-garde, ou même comme un laboratoire de solutions susceptibles de montrer la voie à d'autres secteurs économiques et d'attirer, sous ce jour, toute l'attention des économistes.

3. Mais ce rôle de charnière que l'assurance et son outil privilégié de réflexion, l'Association de Genève, sont appelées à jouer sur le plan international entre l'appel à l'unité, propre à notre époque, et la légitimité des intérêts établis, n'est pas le seul, loin de là. Ce fut le fait du premier Président de l'Association, Raymond Barre, de définir avec netteté le domaine vers lequel celle-ci devait diriger son action. «Soignons, dit-il, les points de contact entre l'assurance privée et les grandes réalités économiques qui l'entourent: l'industrie, la finance, les assurances sociales, les nouvelles technologies, la science économique. Consacrons-nous aux interfaces». C'est cette impulsion transversale que l'Association a mise en pratique au cours de ces vingt années et que le logo qu'elle s'est donné exprime graphiquement.

Grâce à l'apport intellectuel de Genève, l'importance de l'incertitude et du risque comme ingrédients nécessaires de toute entreprise économique a pris son juste relief. L'incertitude, dont les économistes classiques, assis sur les lois universelles de l'ère positiviste, ne croyaient pas devoir tenir compte, domine au contraire la pensée scientifique contemporaine de Schrödinger à Heisenberg ainsi que, sur un autre plan, l'imprévisibilité des systèmes complexes de Mandelbrot à Prigogine. Elle se taille aussi une place de choix dans les réflexions des économistes. Or, les assureurs se disent de par leur métier les experts qualifiés de l'incertitude et du risque; ils se piquent de savoir les mesurer, ils en fixent le prix et prennent à leur charge leurs propres erreurs d'évaluation. Dès lors, l'assurance qui se définissait autrefois comme une simple auxiliaire de l'économie, se révèle au contraire être une composante à part entière, appelée à s'exprimer sur la viabilité de tout projet économique avant même qu'il ne se réalise et tout au long de sa durée. Au plus haut niveau, la fonction du «risk manager», qui est de prévoir les risques et de désigner les moyens d'y faire face, recouvre à certains égards celle du chef d'entreprise. Quel changement de décor! Encore fallait-il le démontrer: l'Association de Genève s'y est appliquée au cours des deux décennies écoulées.

Ses «Annual Lectures» ont vu défiler une série imposante de Prix Nobel et d'éminents protagonistes de la pensée économique contemporaine, de Kenneth Arrow à Jacques Drèze, Martin Feldstein, Walter Weisskopf, Karl Borch, Edmond Malinvaud, Ilya Prigogine - et j'en oublie - tous venus témoigner de l'intérêt que la pratique de l'assurance revêt dans l'avancement de leurs réflexions. 
A un autre échelon, les séminaires annuels du «Groupe Européen des Economistes du Risque et de l'Assurance» sont devenus le lieu obligé de rencontre et de coordination de toute recherche qualifiée à cet égard. Ils contribuent largement au progrès scientifique dans ce champ d'activité.

Les «Geneva Papers» qui sortent régulièrement plusieurs fois par an diffusent parmi leurs abonnés du monde entier la documcntation des résultats des rechcrches menćcs à l'initiative de l'Association, ainsi quc celle des débats qu'elle organise ct dcs assemblćcs qu'elle ticnt chaque année.

4. Par son originc politique ct sa structurc administrative qui recouvre celle de chaque Etat national, la sécurité socialc s'adapte mal aux besoins d'unc économie sans frontières et à la flexibilité de l'emploi qu'clle impliquc. Les institutions restent néccssaircment nationalcs, alors que l'épargne qui l'alimente se veut libre de toute localisation. Unc convergcnce cst donc à trouvcr entre ces dcux positions opposées et l'assurance - dont nous venons de reconnaître la double vocation nationalc et internationale à la fois, est prédestinée à le faire. Par ailleurs, la crise de l'Etat Providence, dénoncée dès le début dcs années '70, rend nécessaire l'apport complémentaire de l'épargne privée. C'est à celle-ci qu'il faut avoir recours pour qu'en dépit de la chute des naissances et des prodigalités indues de la gestion publique en régime de répartition, des retraites adéquates soient garanties aux travailleurs sortant de la vie active sans toutefois grever outre mesure la génération qui en prend la relève.

Voici donc un troisième volet - celui du «Welfare State» et des problèmes sociaux qu'il soulève - auquel l'Association devait naturellement se consacrer. "L'Epargne et la Retraite» - un ouvrage publié en 1982 par Denis Kessler, membre alors du Secrétariat Général et aujourd'hui Président de la Fédération Française des Sociétés d'Assurance - a fait résonner un des premiers sons de cloche au sujet du rôle que l'assurance volontairc avait à jouer pour la solution d'un problème capital des sociétés avancées, celui du troisième âge. L'appel a été entendu des deux côtés de la barrière. D'autres voix qualifiées s'y sont jointes et aujourd'hui, dans la plupart des pays, des mesures de correction du mythe fallacieux de Beveridge - tout à tous, du berceau au cercueil, sans nul effort individuel - sont en cours d'application. Un terrain d'élection de l'assurance libre a été ainsi dćfriché et c'cst peut-être celui qui promet les taux d'expansion les plus élevés.

Continuant sur sa lancée, l'Association a depuis mis à l'étudc sous un jour plus général la condition des pcrsonnes âgćcs. Un véritablc déplacement de l'axe de la vie humaine se produit à notre époque: les jeunes entrcnt plus tard dans la vie professionnelle. Lcs personnes âgécs montrent unc vitalité physique et intellectuelle prolongée, le retraité n'cst plus l'ĉtrc débile d'autrefois, mais se veut membrc actif du corps social, avide d'apprendre, de voyager, de communiquer, donc de dépenser. Lcs retraites, même généreuses, peuventelles lui suffirc? II s'agit donc pour la société d'apprendre à utiliser ces talcnts disponiblcs et pour les rctraités d'accroître leurs revenus: la rencontre de ce deux cxigences forme ainsi un quatrième pilicr au-delà des trois pilicrs classiques de la prévoyance.

11 reste à fairc face au problème inquiétant des frais de santé des personnes âgées. On sait que la moitié des services hospitaliers concerne les malades de plus de 65 ans et qu'aux Etats-Unis les dépenses médicales encourucs pendant la dernière annćc de vie absorbent à elles seules $1 \%$ du PIB. 11 y a là un désćquilibrc grave que les mćcanismes 
d'épargne-assurance devraient pouvoir contribuer à maîtriser: encore un domaine auquel l'Association de Genève consacre une juste attention. Sa vocation de point de rencontre entre les enceintes nationales actuelles et le nouvel ordre international qui se prépare trouve ici d'autant mieux sa raison d'être que le processus de convergence entre les différents régimes de sécurité sociale s'avère très lent, même au sein de la Communauté Economique Européenne.

5. Toujours soucieuse de mettre en relief la contribution que la voix de l'assurance apporte au concert des acteurs principaux de l'économie, l'Association de Genève porte une attention suivie à sa nature de prestatrice de services. La part croissante du tertiaire est un trait dominant de l'ère post-industrielle que nous vivons: on le sait bien. Cette part se révélerait d'ailleurs bien plus importante si des statistiques fiables permettaient de distinguer la portion de «services» qui se cache dans la composition de tout produit présent sur le marché, quel que soit le secteur économique auquel il est attribué d'habitude. La garantie que l'assurance offre étant immatérielle par définition et son contenu ne pouvant être vérifié qu'à posteriori, elle représente le prototype même d'une activité de service. De là l'intérêt que présentent les modes de fonctionnement de l'entreprise d'assurance pour les secteurs similaires - finances, transports, loisirs ou autres - et celui que ces derniers représentent pour l'assureur. Ne fut-ce que dans la sphère cruciale des coûts des services, avec leur marche difforme par rapport à celle des frais industriels, tout effort d'analyse rigoureuse et de comparaison des différentes expériences mérite d'être poursuivi avec ténacité.

Suivant cet ordre de considérations, on en arrive bien vite à se pencher sur les problèmes de la gestion des entreprises d'assurances, de la définition de leurs performances, sur les stratégies que leur conduite suppose, sur les mérites comparés des politiques de concentration ou de subsidiarité. Là aussi, l'Association de Genève joue tout naturellement son rôle de chambre de compensation des expériences, des idées et des solutions qui font surface dans la vaste étendue mondiale de la pratique et de la théorie. Encore une fois elle remplit ici sa mission de facteur de convergence vers un but commun d'efficacité.

6. La voie que nous venons de retracer dans ses grandes lignes était-elle à prévoir aussi clairement il y a vingt ans, lorsque l'Association voyait le jour? Je ne le pense pas. Ses pères fondateurs se sentaient animés surtout par l'idée que l'économie, science relativement jeune alors (si science il y a), était mal représentée parmi les corps de doctrine familiers aux responsables des entreprises d'assurances et à leurs collaborateurs. L'assurance sous sa forme moderne avait été tenue sur ses fonts baptismaux, rappelaient-ils, par des praticiens du droit (pour ce qui a trait au contrat réglant les rapports entre les parties) et par des actuaires (pour le calcul des probabilités et la définition des taux de primes). La gestion financière ne revêtait aux yeux du plus grand nombre qu'une importance secondaire, régie comme elle l'était dans un cadre normatif contraignant par des règles coutumières selon un souci prioritaire de sécurité. Il était temps, leur semblait-il, que l'économie trouve sa place parmi les motifs inspirateurs de la stratégie des entreprises, soit pour mieux définir le rôle que l'assurance avait à jouer dans le contexte économique dont elle faisait partie, soit pour aider à choisir sciemment les voies à suivre pour favoriser son développement ultérieur. L'option internationale du statut de l'Association répondait aussi à un autre souci. Conscients du fait que dans leurs pays respectifs les raisons des assureurs ne rencontraient souvent auprès de l'opinion publique et des autorités gouvernementales 
qu'une oreille distraite sinon prévenue, les promoteurs de l'Association estimaient à juste titre que des positions communes émanant des représentants qualifiés des principaux marchés internationaux d'assurances auraient de meilleures chances d'être acceptées que celles qu'ils pouvaient présenter individuellement dans la défense de leurs intérêts directs. Ces buts éminemment pratiques ont été rejoints et même dépassés à plusieur reprises. Comme il arrive en montagne, de nouveaux paysages sont apparus au fur et à mesure que les premiers sommets étaient atteints. L'assurance figure aujourd'hui à plusieurs titres parmi les réalités acceptées et même parmi les modèles à considérer de la part d'autres acteurs de la vie économique. Son rôle promet de s'étendre ultérieurement dans un monde où le risque est reconnu dans sa fonction stimulatrice de tout progrès, à condition d'être calculable et calculé.

Ce n'est pas un hasard qu'à l'aube du troisième millénaire les systèmes sociaux fondés sur le refus de l'initiative individuelle - donc du risque - s'écroulent et qu'un consensus mondial consacre le succès de l'économie dite de marché. Encore une fois la marche vers l'unité apparaît évidente. L'Association a donc bien procédé dans le sens de l'histoire à notre époque, elle en a, dans son domaine, interprété correctement le sens; elle en a vécu les développements de facon cohérente.

Il faut savoir gré aux animateurs de l'Association de Genève, à la suite éclairée de ses Présidents et de ses Administrateurs, à son Secrétaire Général, M. Orio Giarini, qui en est l'âme, et à ses collaborateurs, de l'avoir pilotée avec autant de courage et autant d'adresse parmi les écueils que tout parcours inexploré comporte. Aujourd'hui l'Association se présente comme une institution essentielle pour que le rôle de l'assurance s'affirme en haut lieu. Son autorité est établie. Elle ouvre à toute la profession un vaste horizon de progrès. 
The Geneva Papers on Risk and Insurance, 18 (No. 68, July 1993), 224-228

\title{
The Geneva Association - Twenty Years on
}

\author{
by Fabio Padoa*
}

1. Twenty years, not even a quarter-century, hardly a blip on the record of historical time, and yet a good half of a full professional life. As our eye takes in the events of this time-span, are we able to discern any lines of convergence, any consistent itinerary?

Let two outstanding master-thinkers of our century, Teilhard and Steiner, serve as guides in our search for an answer to this question. The former has asserted that twentiethcentury man is directed by the sign-post of evolution towards a common destination, that of planetary unity achieved through an ever-widening process of aggregation. The latter, Steiner, identifies within the social order three categories of functions which correspond respectively to the fields of economics, culture and politics. Would it, I wonder, be out of place to attempt in the light of these two propositions to examine the road travelled by the Geneva Association over the last two decades and to decide whether and to what extent the road taken corresponds to the intinerary originally envisaged?

2. Unquestionably, from an economic point of view, the last twenty years have seen enormous progress toward integration in the world we inhabit. Raw materials, industrial products, the movement of capital, and the ebb and flow of economic circumstances have all ceased to be respecters of borders. Trade among all nations of the globe continues to intensify and the process of internationalization has reached out to almost every corner of our planet.

To a lesser, but even so appreciable, extent, the same may be said of spiritual endeavours which tend to be common to minds the world over. This is true of scientific research which cannot be conceived of outside the ongoing colloquium of the world community of scholars. It is true also of religions whose proselytisation takes no cognizancc of the boundaries that divide nations and whose purpose is now an œcumenical onc. And it is truc, finally, of the arts, whether thcy be plastic or musical, which cmploy a single figurative tonguc with which to communicate across the globe with a diversc and distant public.

By contrast, however, sturdy barriers are still to be found in the world of political institutions. The nation state, whose European cxpression it has taken fivc or six centuries to evolve, has produced a closcly woven tissuc of legal, administrative and social forms which inhibit global solutions. Admittedly, the most advanced of European states are now rising to new levels of supranationalism, such as the Union of the Twelve, but

* Honorary President of the Geneva Association. 
at the same time the coming of age of other territorial communities as the yokes of colonial empires in the East and the South are lifted away is creating new nation states in equal number. By their very nature, political structures and the institutions they influence run counter to that prevailing movement towards global unity which, by contrast, is all too apparent in the worlds of economics and culture. Because of this, then, political institutions may be said to constitute a fault-line in the unification process.

Now insurance, by reason of its dual status - national because it is solidly rooted in the institutional soil of the state within which it operates, and international because it is a mechanism for spreading risk in space beyond the confines of national frontiers - plays an exemplary role at a time when the contradiction we have just examined is so acutely manifest. As a place of research and analysis where raw data is given theoretical significance, the Geneva Association is ideally placed to promote insurance as an avantgarde domain, as a kind of pilot laboratory whose solutions will open up the way for other sectors of the economy and, precisely because of this, attract the full attention of economists.

3. But this hinge function that insurance and the Geneva Association, its dedicated instrument of reflexion, are called upon to perform internationally by reconciling that call to unity so characteristic of our age with the legitimate entitlement of vested interest, is by no means their only function. Was it not Raymond Barre, the first President of the Association, who so precisely defined the focus of the Association's activities? He said: "Let us concern ourselves with those places where private insurance makes contact with the major features of the surrounding economic environment - industry, finance, social insurance, new technologies and economic science. In other words, let us concentrate on the interface zones". This is precisely the transverse approach that the Geneva Association has attempted to build into its activities over the past twenty years, an approach to which the Association's logo gives eloquent graphic expression.

Thanks to the Geneva Association's intellectual contribution, the importance of uncertainty and risk as inevitable ingredients in any economic venture has ben brought into proper perspective. Uncertainty, disregarded by classical economists whose thinking was grounded in the universal laws of the age of positivism, has, on the contrary, now come to dominate contemporary scientific thinking from Schrödinger to Heisenberg and, at a rather different level in respect of the unpredictable nature of complex systems, from Mandelbrot to Prigogine. Uncertainty is, then, beginning to occupy a prominent place in the minds of economists. Now insurers, by virtue of their trade, hold themselves to be experts in matters of risk and uncertainty. They pride themselves on being able to assess and evaluate the latter, and, in so doing, remain ready to bear responsibility for any error of judgement they make. Insurance, then, which in times past was deemed to be something ancillary, has become one of the major components of the economy, and is now used in assessing the feasibility of any economic undertaking before the latter is embarked upon and throughout its execution. At the very highest level, the job of "risk manager" - to assess risk and devise methods of coping with it - in many ways duplicates that of the director of an enterprise. How things have changed! And yet the need for such change had to be demonstrated and its significance explored, and this precisely has been one of the Geneva Association's tasks over the past two decades.

Its "Annual Lectures" have been delivered by a very impressive array of Nobel Prizewinners and other eminent exponents of contemporary economic and scientific thought, 
including Kenneth Arrow, Jacques Drèze, Martin Feldstein, Walter Weisskopf, Karl Borch, Edmond Malinvaud, Karl Popper, Ilya Prigogine - and there are others - all of whom have testified to the relevance of insurance practice to the development of their disciplines and thinking.

At another level, the annual seminars of the "European Group of Risk and Insurance Economists" have become indispensible fora for the exchange and coordination of serious scientific research, and have thus made a significant contribution to scientific progress in this domain.

The "Geneva Papers" which appear at regular intervals in the year circulate to their subscribers the world over the results of research undertaken on the Association's initiative as well as reports on the various discussion-groups and meetings the Association organizes throughout the year.

4. Social Security, because of its political roots and its administrative structure which coincides closely with that of the nation state, has been slow to adapt to the requirements of the frontier-free economy and to the flexible labour patterns the latter entails. Institutions remain ineluctably national and local while the savings that feed them aspire to extraterritorial status. There is therefore a conflict of opposites here that needs to be resolved and insurance, possessed as it is of the dual national and international status we have just described, is fated to provide that resolution. Moreover, the crisis affecting the Welfare State which was first publicized at the beginning of the 70s now makes an additional contribution from private savings unavoidable. Indeed, inspite of the fall in the birth-rate and the excessively generous public management of the pay-as-you-go system, if adequate pensions are to be guaranteed to workers leaving active life without placing too heavy a burden upon the generation that takes over, then recourse to private savings becomes inevitable.

The "Welfare State" and the social problems to which it gives rise have, then, proved a third natural focus for the Geneva Association's activity. "L'Epargne et la Retraite (Savings and Retirement)" - a work by Denis Kessler published in 1982 (Kessler has been in the meantime a member of the General Secretariat and today is President of the French Federation of Insurance Companies) - sounded the first of a series of warning bells about the necessary role of non-compulsory insurance in helping to solve one major problem facing all advanced societies, namely, that posed by a rapidly expanding Third-Age generation. The warning was heared by people on both sides of the fence, and was endorsed by other eminent voices so that, today, in most countries corrective measures are now being taken to palliate the effects of Beveridge's fallacious myth - all for all, from cradle to grave, with nothing asked of the individual. Preferential pastures were thus opened up for noncompulsory insurance, an area which promises one of the highest rates of growth.

Thus set on course, the Association has since begun to examine in a more general way the situation of older people. A complete change in the human lifecycle profile has taken place in our time: the young enter professional life later; older people display physical and mental vitality until much later in life; the retiree is no longer the diminished individual of former times, but is now anxious to remain an active and able member of the community bent on learning more, on travelling, on communicating with others, and is thereby ready to spend. In these circumstances, will even a generous pension suffice? So society must learn to make use of the retiree's skills and talents and the latter must find some means of increasing his or her income. The meeting place of these two requirements is a Fourth Pillar to be added to the three that already exist within the classical welfare structure. 
There remains, then, the worrying problem of the health costs of the elderly. It is now common knowledge that one half of the care resources in hospital systems has to be devoted to patients of 65 years and over, and that in the United States medical costs incurred during the last year of life alone account for $1 \%$ of the GDP. There is here a very serious imbalance which savings-insurance mechanisms should help to rectify - another very proper focus of the Geneva Association's attention. Indeed, its vocation as a meeting-place for existing national institutions with the new international order in the making is especially valuable since the process of convergence between the different social security systems is very slow, even within the European Economic Community.

5. In its constant concern to highlight the contribution that the voice of insurance can make in the debate that now engages the main actors of the economy, the Geneva Association has given close attention to insurance as a provider of services. The growing share of the tertiary sector in the economy is a predominent trait of the post-industrial age we live in. That much is common knowledge. Yet, that share would be discovered to be much larger were onc to produce reliable statistics that separated out the "services" component that lies concealed within the make-up of any product on the market, regardless of the economic sector to which the latter is normally attributed. Now since the warranty offered by insurance is by definition immaterial and since its content can only be verified a posteriori it can be said that insurance constitutes the very prototype of a service activity. Hence the relevance of an insurance firm's modes of operation to other similar sectors of the economy finance, transport, leisure and so on - and, by the same token, the relevance of the latter to insurers. If only in the crucial area of service costs, with their distorted profile as compared with that of industrial costs, any stringent analysis and comparison of different experiences deserves to be pursued with tenacity of purpose.

It was against this background that attention quickly began to focus on the problems of the management of insurance undertakings and of defining their performance, on the strategies that their behavior subsumes, and on the relative merits of policies for concentration and subsidiarity. Once again the Geneva Association has played a natural and proper part by becoming a clearing-house for the ideas, experiments and solutions which surface across the vaste waters of practice and theory worldwide. And once again the Association has accomplished its mission as an agent of convergence in helping its members towards a common goal of efficiency.

6. The itinerary we have just described in very broad terms, could it, I wonder, have been forseen twenty years ago when the Association was born? I think not. The founding fathers were inspired above all by the idea that economics, a relatively young science (if science, indeed, it was and is), was a poor relation of the doctrines commonly familiar to the heads of insurance firms and their assistants. Insurance in its present form was held over the baptismal font, the fathers reminded us, by practioners of law (in so far as it resembled a contract governing the relations between two parties) and by actuaries (for the purposes of calculating probabilities and fixing premium rates). Financial management was seen by most insurers as an issue of secondary importance since it was subject to standard practices governed by principles of common law which alongside the other determinants of enterprise strategy both in order better to define the role of insurance in the economic environment in which it belonged or and to be able to make deliberate and informed choices about how best to develop insurance in the future. But the decision to found an Association of international scope reflected yet another concern. Aware that in their respective countries the 
arguments of insurers were hardly ever given more than a cursory hearing by public opinion or government authorities, the promoters of the Association rightly felt that common positions which reflected the views of the qualified representatives of the main international insurance makets stood a better chance of being listened to than any position that they, as individuals, might put forward in defence of their immediate concerns. Indeed, these eminently practical aims were achieved and even exceeded on a number of occasions. As so often happens in the mountains, fresh horizons are discovered even as earlier ones are reached. And, in more than one respect, insurance is today one of the accepted facts, and a model even, to be taken into consideration by actors in other walks of economic life. The role of insurance is, indeed, destined to grow in a world where risk, provided it remains assessable and assessed, is now accepted as one of the triggers of progress.

It is no accident that, on the threshold of the third millenium, social systems based on a rejection of individual initiative - and therefore of risk - are beginning to collapse and that a world consensus now celebrates the success of the so-called market economy. And once again the movement towards unity is manifest. The Association has indeed been moving with the flow of contemporary history and has managed, in its own field, correctly to interpret the sense of that flow. It has, in other words, moved meaningfully with the times.

Once must credit the founders of the Geneva Association, and thereafter its enlightened Presidents and Administrators, and the Secretary General, Mr. Orio Giarini, the embodiment of the Association's essential spirit, and his assistants, with having managed to steer their craft with such courage and skill through the reefstrewn waters to be found in all uncharted seas. The Association has now become essential to the task of securing for insurance the high-level role it deserves, and its authority can no longer be questioned, for it has set before the insurance profession as a whole a vast agenda for progress. 